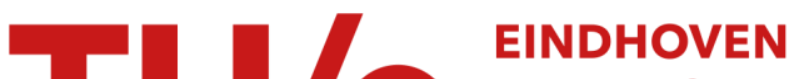 \\ UNIVERSITY OF \\ TECHNOLOGY
}

\section{Injection molding of zirconia (Y-TZP) ceramics}

Citation for published version (APA):

With, de, G., \& Witbreuk, P. N. M. (1993). Injection molding of zirconia (Y-TZP) ceramics. Journal of the European Ceramic Society, 12(5), 343-351. https://doi.org/10.1016/0955-2219(93)90003-A

DOI:

10.1016/0955-2219(93)90003-A

Document status and date:

Published: 01/01/1993

\section{Document Version:}

Publisher's PDF, also known as Version of Record (includes final page, issue and volume numbers)

\section{Please check the document version of this publication:}

- A submitted manuscript is the version of the article upon submission and before peer-review. There can be important differences between the submitted version and the official published version of record. People interested in the research are advised to contact the author for the final version of the publication, or visit the $\mathrm{DOI}$ to the publisher's website.

- The final author version and the galley proof are versions of the publication after peer review.

- The final published version features the final layout of the paper including the volume, issue and page numbers.

Link to publication

\section{General rights}

Copyright and moral rights for the publications made accessible in the public portal are retained by the authors and/or other copyright owners and it is a condition of accessing publications that users recognise and abide by the legal requirements associated with these rights.

- Users may download and print one copy of any publication from the public portal for the purpose of private study or research.

- You may not further distribute the material or use it for any profit-making activity or commercial gain

- You may freely distribute the URL identifying the publication in the public portal.

If the publication is distributed under the terms of Article 25fa of the Dutch Copyright Act, indicated by the "Taverne" license above, please follow below link for the End User Agreement:

www.tue.nl/taverne

Take down policy

If you believe that this document breaches copyright please contact us at:

openaccess@tue.nl

providing details and we will investigate your claim. 


\title{
Injection Moulding of Zirconia (Y-TZP) Ceramics
}

\author{
G. de With* \& P. N. M. Witbreuk \\ Philips Research Laboratories, PO Box 80000, 5600 JA, Eindhoven, The Netherlands
}

(Received 26 March 1993; revised version received 3 June 1993; accepted 15 June 1993)

\begin{abstract}
Injection moulding of ceramics (CIM) is considered as a promising shaping technique. An investigation was started to test whether injection moulding of Ittrium oxide stabilized tetragonal zirconia polycrystals $(Y-T Z P)$ can result in products with good mechanical properties.

The production of Y-TZP CIM parts appears to be feasible. The choice of ceramic powder and binder removal procedure are the critical process steps. Study. of the binder removal process indicates that oxidative d'gradation of the binders at the polymer-gas interface is the predominant mechanism.

The strength and cariability of strength of the $Y$ $T Z P$ parts produced compare favourably to those of commercially available Y-TZP materials. As shown by the statistical range of various size measurements. the shape reproducibility uas 1-3\%. but appears to he very dependent on shape and product support during the hinder removal process.
\end{abstract}

Das Spritzgießen von Keramiken (CIM) wird als eine vielversprechende Formgebungstechnik betrachtet. Es wurde untersucht, ob die Spritzgießprodukte, hergestellt aus Yttriumoxid stabilisiertem, tetragonalem polykristallinem Zirkoniumoxid $(Y-T Z P)$, gute mechanische Eigenschaften haben.

Die Herstellung von Y-TZP CIM erscheint möglich. Die Wahl des Keramikpulvers und das Verfahren zur Entfernung des Binders bilden die kritischen Prozeßsschritte. Die Untersuchung des Binderentfernungsprozesses weist darauf hin, daß die oxidative Degeneration des Binders an der Polymer-GasGrenzfläche der entscheidende Mechanismus ist.

Ein Vergleich der Festigkeit und der Festigkeitsvariation zwischen den hergestellten Y-TZP-Teilen

* Also affiliated to the Centre for Technical Ceramics, Eindhoven University of Technology, PO Box 513, 5600 MD, Eindhoven, The Netherlands. und kommerziell erhältlichen Y-TZP-Materialien fällt zugunsten der ersteren aus. Die statistische Breite verschiedener Größrenmessungen zeigt eine Reproduzierbarkeit der Formen von 1-3\%, hängt aber offensichtlich sehr von der Form und der mechanischen Stützung des Produkts während der Entfernung des Binders ab.

Le moulage des céramiques par injection (CIM) est considéré comme une technique de formage prometteuse. Nous avons commencé une étude afin de tester si le moulage par injection de zircone tétragonale polycristalline stabilisée par de l'oxyde dittrium ( $Y$-TZP) permet d'ohtenir des produits qui présentent des propriétés mécaniques satisfaisantes.

Il est effectivement possible de mouler des pièces de zircone ( $Y-T Z P$ ) par injection. Les étapes critiques sont le choir de la poudre céramique et l'élimination du liant. L'étude de ce phénomène d'élimination montre que le mécanisme principal en est l'oxydation du liant à l'interface gaz-polymère.

La résistance des pièces de zircone $(Y-T Z P)$ produites, et sa reproductibilité, sont meilleures que celles de la zircone disponible dans le commerce. Une statistique des différentes dimensions mesurées indique une reproductibilité de la forme des pièces de I à $3 \%$, mais celle-ci dépend sensiblement de la forme voulue et du moule utilisé lors de l'élimination du liant.

\section{Introduction}

There are different types of zirconia-based structural ceramics such as partially stabilized zirconia (PSZ) and tetragonal zirconia polycrystal (TZP). They can be used in cutting tools, wire drawing and hot extrusion dies, seals in valves and pumps and for internal combustion engine parts. Fully tetragonal stabilized zirconia with yttrium oxide (Y-TZP) in particular is a structural ceramic with interesting mechanical properties. A reasonable compromise 343

Journal of the European Ceramic Society 0955-2219/93/\$6.00 1993 Elsevier Science Publishers Ltd, England. Printed in Great Britain 
between strength and fracture toughness can be found in this material.

Injection moulding is an interesting shaping technique when a large number of identical parts are needed. ${ }^{1}$ The method offers a large degree of shape freedom. It is a near net shaping technique due to the high homogeneity of the green parts. It is also important that the mechanical properties of a ceramic prepared by this method achieve the same level as they do in other forming techniques. Because of the favourable properties of Y-TZP, this material was chosen for producing parts made by injection moulding. The aims of this investigation were therefore:

- Producing injection-moulded Y-TZP parts.

- Obtaining insight into the mechanism of binder removal because this is the part of the process in which flaws are often introduced.

- Determining the strength and homogeneity of the injection-moulded Y-TZP parts and comparing them with values for conventionally formed Y-TZP parts.

- Obtaining insight in the shape reproducibility of products made by the ceramic injectionmoulding process.

These aspects are discussed in Sections 2 to 5, respectively.

\section{Injection Moulding Y-TZP Parts}

The injection-moulding process consists of various steps. In the next sections these steps are discussed together with their accompanying analysis.

\subsection{Mass recipe and powder choice}

The recipe used for making the injection moulding mass contained the following ingredients:

-A primary binder based on a 2:1 mixture of polyethylenevinylacetate (Platabond M1222, Deutsche ATOchem Werke, melting range $75-85^{\circ} \mathrm{C}$ ) and a copolyamide (Platamid $\mathrm{H} 005$ PA 80, Deutsche ATOchem Werke, melting range $\left.115-125^{\circ} \mathrm{C}\right), 82 \mathrm{~g}$ in total;

-dioctylphthalate as plasticizer $(30 \mathrm{~g})$;

-fatty acid polyglycol (Serdox NSG 400, Servo

BV) ester as softening agent $(25 \mathrm{~g})$;

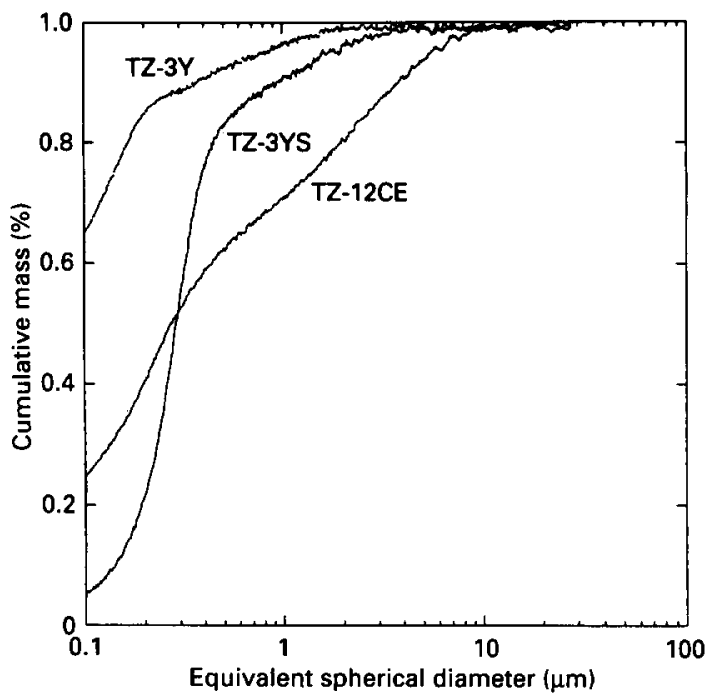

Fig. 1. Particle size distribution of the zirconia powders A, B and $\mathrm{C}$.

-zinc stearate (Haagen Chemie) as lubricant ( $8 \mathrm{~g}$ );

- Servoxyl VPNZ 10/100 (Servo BV) as a wetting agent $(5 \mathrm{~g})$; and

- the ceramic powder $(1024 \mathrm{~g})$.

There are several requirements for the ceramic powder. ${ }^{2}$ The particle size distribution and the particle form are of importance. These parameters should be optimized to achieve the highest volume loading of ceramic powder in the injection moulding mass. A high volume loading ceramic powder gives a high green density (strong green product) and there is less binder to remove.

Three injection moulding masses were made (see Section 2.2) with binder system already described but with three different types of zirconia powder, all with $3 \mathrm{~mol} \% \mathrm{Y}_{2} \mathrm{O}_{3}$ (Table 1). In Fig. 1 the particle size distributions of the three powders are shown. The size distributions were measured with a sedigraph (Micromeritics SediGraph 5000D, $5 \mathrm{wt} \%$ powder in $\mathrm{H}_{2} \mathrm{O}$ using $1 \mathrm{~g} / \mathrm{dm}^{3} \mathrm{Na}_{4} \mathrm{P}_{2} \mathrm{O}_{7} \cdot 10 \mathrm{H}_{2} \mathrm{O}$ as dispersing agent). It can be seen that powder $\mathrm{A}$ has the smallest particles with a wide distribution. Powder B has a narrow particle size distribution with a larger mean size and powder $C$ has a much broader distribution with approximately the same mean size as powder $\mathrm{B}$. With powder $\mathrm{C}$ the highest volume loading of ceramic powder in the injection moulding mass could be achieved, while the use of powder A resulted in a low loaded ceramic mass. The

Table 1. Powder characteristics

\begin{tabular}{ccccc}
\hline Type & $\begin{array}{c}\text { Specific surface } \\
\text { area } \\
S\left(\mathrm{~m}^{2} / g\right)\end{array}$ & $\begin{array}{c}\text { Mean particle } \\
\text { size } \\
d(\mu \mathrm{m})\end{array}$ & $\begin{array}{c}\text { Maximum usable } \\
\text { percentage solid } \\
\text { in the mass } \\
(w+\%)\end{array}$ & Producer \\
\hline A & 17 & $<0.1$ & 82 & Tosoh TZ-3Y \\
B & 6.8 & 0.29 & 87 & Tosoh TZ-3YS \\
C & 11.2 & 0.27 & 89 & Tosoh TZ-12CE \\
\hline
\end{tabular}


masses of the three powders had comparable flow properties. After binder removal unbroken parts were obtained only with powder $B$, which was therefore chosen for further work.

\subsection{Mixing and plasticizing}

The next steps are the mixing of the ceramic powder with the organic binders and the plasticizing of the mixture to a dough with sufficiently low viscosity. Mixing of the ceramic and polymer powders was done in a polyethylene jar (diameter $125 \mathrm{~mm}$ ) on a roller bench for $1 \mathrm{~h}$ at $100 \mathrm{rpm}$. Plasticizing was done in a Z-blade mixer (Werner \& Pfleiderer, type LUK 0.75). The Z-blade mixer was thermally equilibrated for $1 \mathrm{~h}$ before use. After the mixer was turned on, about half of the powder mixture was put in. Next the liquid was added to the powder mixture in the mixer. Mixing was done until full plasticization occurred. From this point on the rest of the powder was slowly added, while keeping the mass plasticized. The process has to last for at least $1 \mathrm{~h}$.

In the plasticization process not only are the organic binder system and the ceramic powder homogeneously mixed, but the agglomerates in the ceramic powder are also reduced in size. In Fig. 2 the particle size distributions of the as-received powder and of the powder after mixing and binder removal are shown. The size distributions were measured as indicated before. In both cases the dispersion was ultrasonically mixed for $2 \mathrm{~min}$. It was shown that 2,4 or $15 \mathrm{~min}$ sonification gave no change in the particle size distribution. From Fig. 2 it can be seen that the curve is moved towards a smaller particle size and that the amount of coarse particles is reduced.

\subsection{Injection moulding}

After the mixing/kneading process was terminated, the injection moulding mass was taken out of the mixer and cut into pieces of approximately

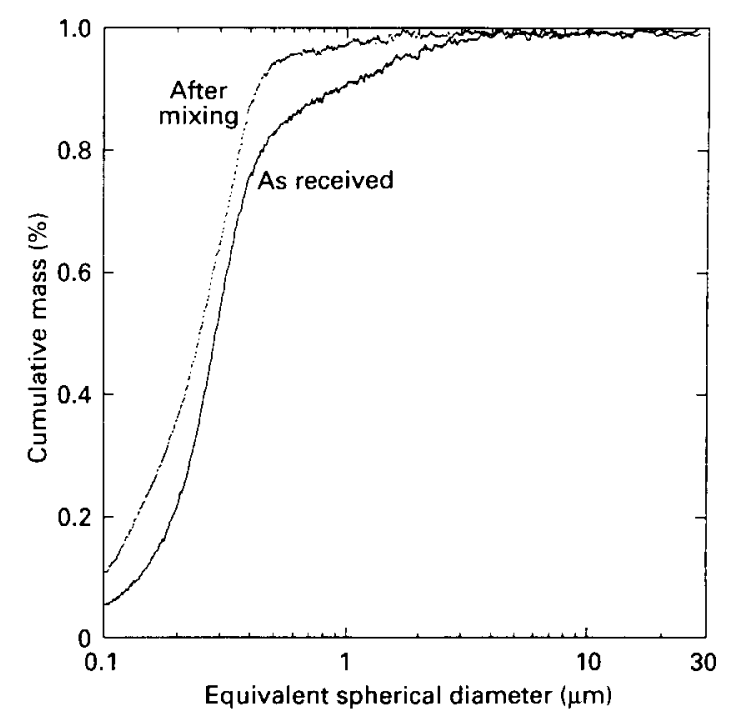

Fig. 2. Particle size distribution of the as-received powder and of the powder after mixing and binder removal.
$1 \times 1 \times 1 \mathrm{~cm}^{3}$ which, after cooling, were broken in a so-called granulator (Pallmann type 1) to produce pieces of less than $5 \mathrm{~mm}$.

The injection moulding machine used for the experiments was a Boy $15 \mathrm{~S}$, a screw plastification in-line type with three heating zones. Before an injection moulding run was done the machine was thermally equilibrated. The injection moulding mass was given a temperature as high as possible. The first zone was adjusted to $160 \mathrm{C}$ and the second to $190^{\circ} \mathrm{C}$. The third, the injection nozzle heater, ranged from 170 to $195 \mathrm{C}$. The filling of the mould was done in one stage with 125 bar in the forward mode of the injection screw. The injection pressure was held for just $3 \mathrm{~s}$ because the sprue freezes really quickly and heat transfer from the injection nozzle to the runner ejector must be minimized. After an injection the screw starts rotating to feed new mass to the front of the plastification screw. The contact time between injection nozzle and runner ejector was $6 \mathrm{~s}$. The cooling time was $20 \mathrm{~s}$. Complete shrinkage of product and runner is necessary before ejection starts. The ejection time was $1 \mathrm{~s}$.

\subsection{Binder removal and sintering}

The next step, binder removal, was done in a chamber furnace (Allino type EGH 20/40). In the chamber an alumina box was placed with inside dimensions of $460 \times 155 \times 125 \mathrm{~mm}^{3}$. This box separated the products from the heating elements. The air in the furnace was constantly renewed at a rate of a few liters per hour. The temperature program used for binder removal, which in total lasts $56 \mathrm{~h}$, consisted of three steps:

-With $150 \mathrm{C} / \mathrm{h}$ to $140 \mathrm{C}$, no dwell.

-With $5 \mathrm{C} / \mathrm{h}$ to $400 \mathrm{C}$, no dwell.

-With $150 \mathrm{C}$ h to $20 \mathrm{C}$, no dwell.

The injection-moulded products were placed horizontally on porous stainless-steel substrates of size $165 \times 125 \times 2 \mathrm{~mm}^{3}$. The substrates have a smooth surface and the porosity permits easy gas flow through the plate. Despite this precaution, the injection-moulded disks (diameter $61 \mathrm{~mm}$, thickness $2.3 \mathrm{~mm}$ ) were still spherically deformed after the binder removal process. The flatness, measured as the out-of-plane distance in the centre of the plate with respect to a plane defined by the edge of the plate, is $0.2 \mathrm{~mm}$. A smooth surface of the stainlesssteel substrates is necessary because during the process the products become plastic and a rough substrate will then give imprints on the products.

Finally, the sintering of the green products was done in a chamber furnace (Naber model LHT 4R). To obtain a zirconia part that is fully tetragonally stabilized, the particle size may not exceed $0.8 \mu \mathrm{m}$ $\left(3 \mathrm{~mol} \% \quad \mathrm{Y}_{2} \mathrm{O}_{3}\right)$. Therefore a temperature-time 


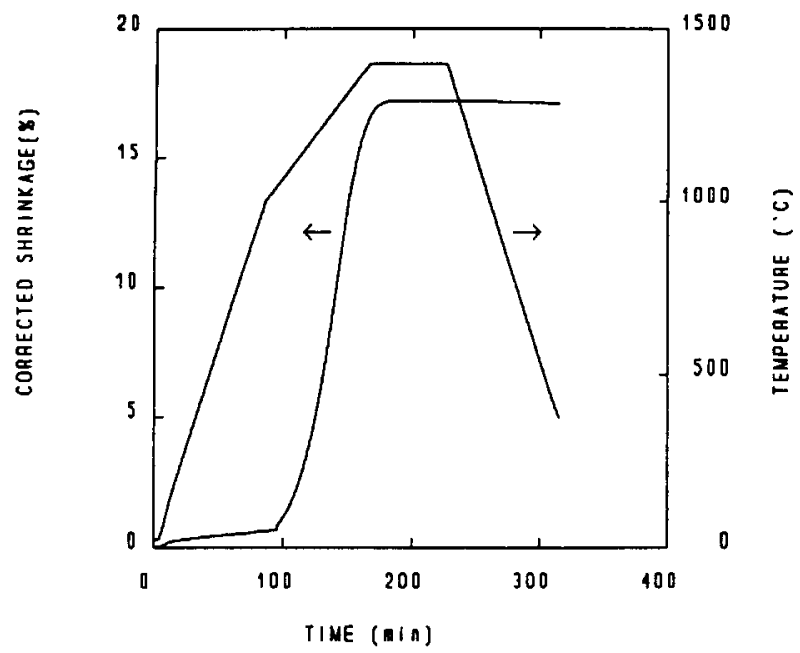

Fig. 3. Sintering schedule and resulting shrinkage of the injection-moulded part.

profile was determined in which full densification occurred, but no excessive grain growth took place. The optimal sintering curve and corresponding shrinkage is shown in Fig. 3. Up to $1000^{\circ} \mathrm{C}$ the heating rate was about $15^{\circ} \mathrm{C} / \mathrm{min}$, while in the range from $1000^{\circ} \mathrm{C}$ to $1400^{\circ} \mathrm{C}$ the heating rate was about $6^{\circ} \mathrm{C} / \mathrm{min}$. The temperature was kept at $1400^{\circ} \mathrm{C}$ for $1 \mathrm{~h}$.

From the dilatometric measurements it is clear that densification takes place from $1000^{\circ} \mathrm{C}$ to $1400^{\circ} \mathrm{C}$. The sinter shrinkage was $17 \cdot 2 \%$, while the overall shrinkage of the injection-moulded disks was $18.4 \%$, as calculated from size measurements on product and mould cavity.

Besides test disks of diameter 61 and $30 \mathrm{~mm}$, other shapes were also injection moulded. In Fig. 4 all shapes which were made are shown. In a composite mould with four cavities, two different rings, a

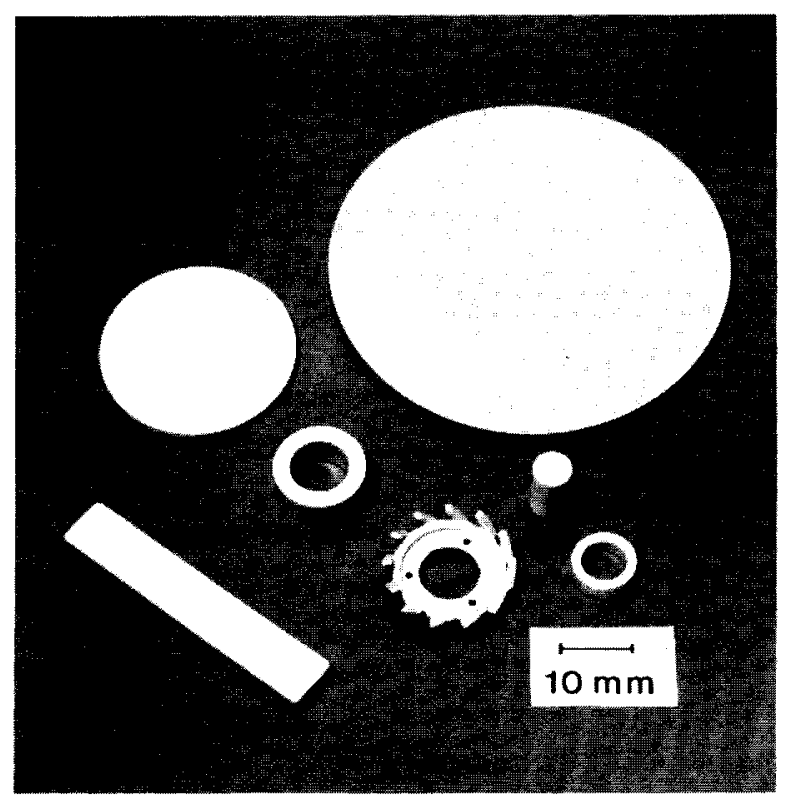

Fig. 4. Various injection-moulded Y-TZP ceramic parts. Apart from the various standard shapes such as rings, disks and bars, a complex-shaped shaver knife is also shown. cylinder and a beam could be made. A highly complex shape also produced is a shaver blade.

\subsection{Microstructure and roughness}

Figure 5(a) shows the surface of a binder-removed injection-moulded cylinder. The separate particles and pores of a few micrometers can be distinguished. The surface after sintering is shown in Fig. 5(b). After sintering the larger pores have disappeared

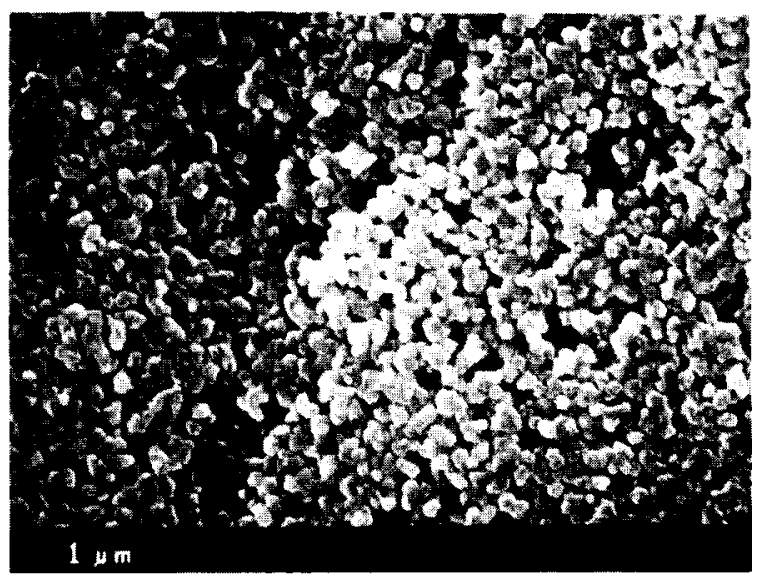

(a)

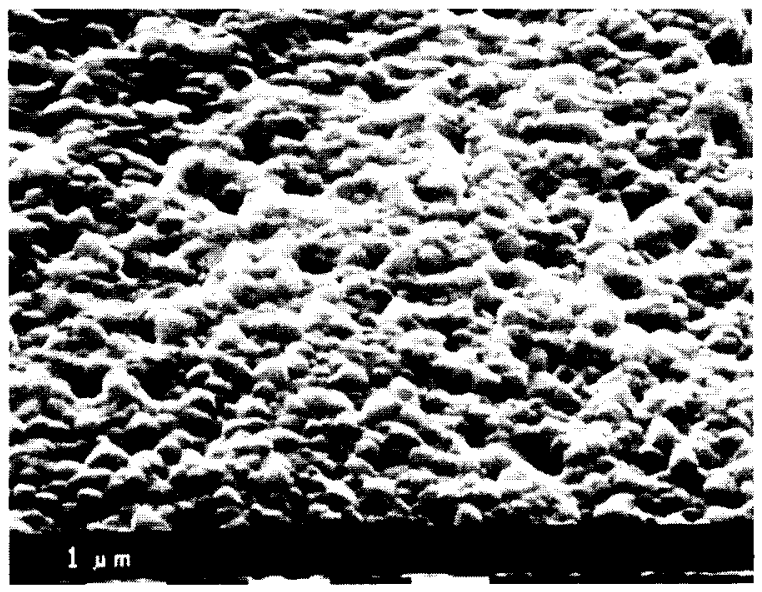

(b)

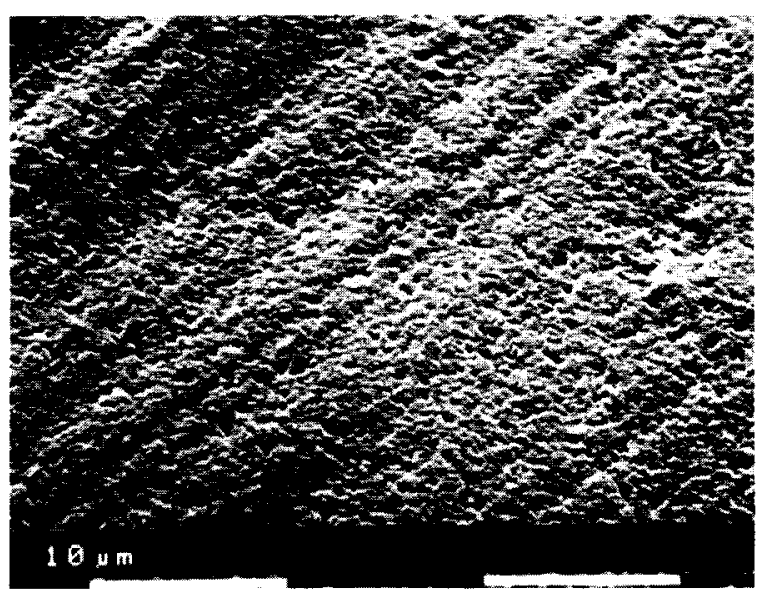

(c)

Fig. 5. Surface of a cylinder (a) from which the binder has been removed, (b) which has been sintered showing the grains and some pores and (c) the sintered surface at lower magnification showing the imprint of the machined surface of the mould. 
and the particles are closely packed. The grain size is still approximately $0.3 \mu \mathrm{m}$, as also found with the sedimentation measurements for the powder. The short sintering time and low temperature during densification therefore prevented excessive grain growth. On the sintered surface pores with a diameter smaller than $0.5 \mu \mathrm{m}$ are present. X-ray diffraction revealed that the sintered products were tetragonal $\mathrm{ZrO}_{2}$.

The surface roughness (Taylor-Hobson talysurf 6) of the shaver knives, expressed as an $R_{\mathrm{a}}$ value, is about $0.2 \mu \mathrm{m}$ higher than the surface roughness of the mould cavity, although the $R_{\mathrm{a}}$ value on the same location as for the product was difficult to determine for the mould. The $R_{\mathrm{a}}$ value is higher because of the porosity and the grain structure present (see Fig. 5(b)). Figure 5(c) shows the surface texture of an injection-moulded cylinder at lower magnification. It can be clearly seen that the grinding traces of the cavity surface are reproduced on the surface of the fired product.

\section{The Binder Removal Process}

To find process conditions during which the binder can be completely removed from the products without damage or dimensional change, further insight into the binder removal process is necessary. The temperature dependence of the binder removal process was accordingly investigated with thermogravimetric analysis (TGA). The pore structure development during binder removal was studied by $\mathrm{N}_{2}$ gas adsorption analysis (BET) and mercury intrusion porosimetry (MIP).

\subsection{Optimizing the temperature-time schedule}

Optimizing the binder removal temperature schedule means searching for a weight reduction curve with a constant gradient but without abrupt gradient changes. A high weight reduction rate means a high decomposition/volatilization rate of organic compounds which is accompanied by internal pressurizing and thus mechanical loading of the injection-moulded part. The latter can easily result in failure of the compact. For pieces of $0.3 \mathrm{~g}$ of an injection-moulded disk of the same composition as mentioned in Section 2.1, the binder was removed during TGA measurements. In Fig. 6 the weight loss curves for heating rates of 5,10 and $15^{\circ} \mathrm{C} / \mathrm{h}$ are shown. A heating rate of $5 \mathrm{C}$ gives the best curve. At a heating rate of 10 and $15^{\circ} \mathrm{C} / \mathrm{h}$ the curves have a steep gradient at the end of the heating curve where the injection-moulded part is very weak and brittle.

The effect of the presence of ceramic powder and of the size of the injected-moulded part on the binder removal process was studied with TGA using a

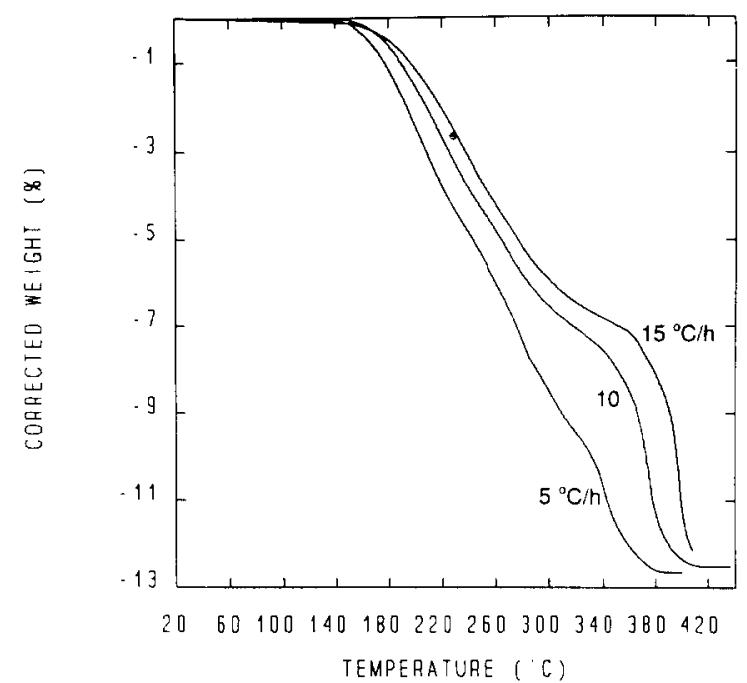

Fig. 6. Weight reduction during binder removal at a heating rate of 5,10 and $15 \mathrm{C} / \mathrm{h}$.

heating rate of $5 \mathrm{C} / \mathrm{h}$. The presence of ceramic powder in the binder results in a smoother weight reduction curve without abrupt gradient changes above $300^{\circ} \mathrm{C}$, but with a larger absolute value of the gradient. Probably the polymer-gas interface is larger, which accelerates the binder removal. As the injection-moulded product becomes thicker, the weight-temperature curve also becomes more nonlinear, resulting in a large gradient change above $350 \mathrm{C}$. In this case the exchange of the binder removal products and oxygen through the pores becomes more difficult as the process proceeds. Thus larger products need more air refreshment and a lower heating rate.

\subsection{The binder removal mechanism}

The binder removal mechanism is probably a combination of processes:

-Evaporation of low molecular weight polymers.

- Oxidative degradation (combustion).

- Thermal degradation of higher molecular weight polymers followed by evaporation of degradation products.

Evaporation and oxidative degradation are processes which take place at or near the polymer-gas interface. ${ }^{3.4}$ In this case a simple representation of the binder removal process is therefore the shrinking core' model. Partially binder-removed products contain a non-porous core of ceramic powder and binder and a shell containing only ceramic powder and open pores. The core shrinks as a function of temperature and/or time. The fact that oxidative degradation is restricted to the polymer-gas interface means that the degradation products can disappear freely through the porous shell and put no mechanical load on the product.

Thermal degradation can proceed throughout the product body but the reaction products can only be 


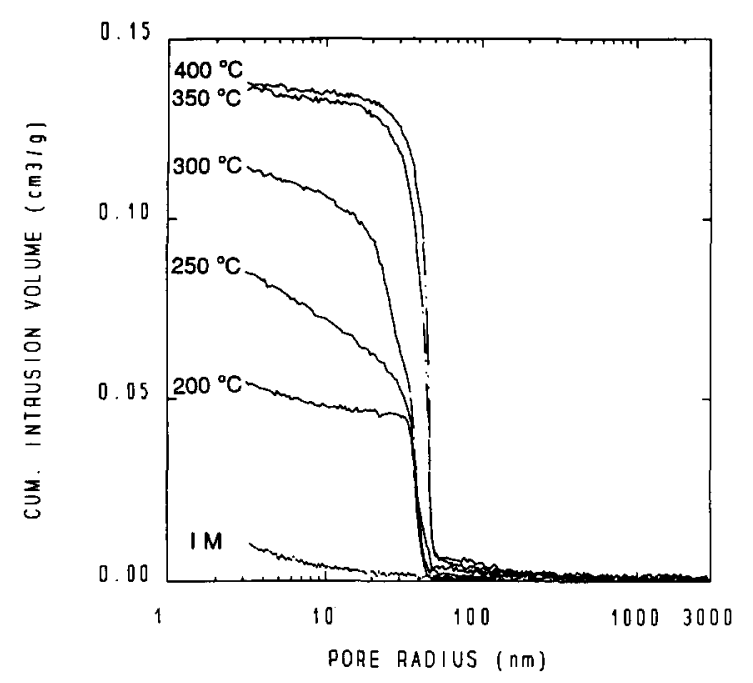

Fig. 7. Cumulative pore volume of injection-moulded cylinders for which the binder removal process has been cut off at 200,250 , 300,350 and $400^{\circ} \mathrm{C}$. The curve indicated with IM represents the as-injection-moulded cylinder.

removed without damage if they have chance to diffuse outwards and disappear at the surface. Since the reaction products arising within the piece cannot diffuse freely, the product will be loaded mechanically.

For most organic materials used in the binder system, the activation energy for oxidative degradation is much lower than for thermal degradation. Therefore it is expected that evaporation and oxidative degradation will dominate at low temperature. Only when there is a lack of oxygen or when the temperature is raised quickly to levels where thermal degradation will dominate, will the process also take place away from the polymer-gas interface.

If the weight reduction is based on oxidative degradation, the shell volume of the injectionmoulded product must be directly related to the weight reduction. In Fig. 7 the cumulative pore volume curves are shown for several injectionmoulded cylinders. The binder removal process was cut off at $200,250,300,350$ and $400^{\circ} \mathrm{C}$ after which the weight and pore volume were measured. The difference in pore volume as measured with the MIP measurements and as calculated from the weight difference before and after binder removal is shown in Table 2.

The differences between the measured pore volumes and the calculated pore volumes are small. This indicates that the shrinking core model is appropriate. The core shrinks with increasing temperature and has disappeared at approximately $350^{\circ} \mathrm{C}$. Figure 7 shows that the pores have a radius of $50 \mathrm{~nm}$ and that their volume grows with increasing binder removal temperature while their size remains constant. This is also consistent with the shrinking core model.

The MIP measurements for cylinders with binder removed up to 250 and $300^{\circ} \mathrm{C}$ show also some intrusion at high pressure which could be interpreted as micro-pores (smaller than $30 \mathrm{~nm}$ ). Whether such pores really exist is not a priori clear. Probably, this intruded volume represents overall compression of the cylinders due to the binder in the core. Indeed, with BET measurements no increased pore volume between 2 and $30 \mathrm{~nm}$ is observed for cylinders with binder removed up to 250 and $300^{\circ} \mathrm{C}$ as compared with cylinders with binder removed up to 350 and $400^{\circ} \mathrm{C}$. Therefore it is concluded that no micro-pores are present and the high pressure intrusion is due to compression effects.

\section{Mechanical Properties}

The mechanical properties of a structural ceramic are important for their application. Firstly, the experimental details concerning the testing are given. Secondly, the results are discussed and compared with the data for commercially available materials. Finally, the influence of plasticizing time on the strength is discussed.

\subsection{Description of the mechanical tests}

For the sintered ceramics, the density $(\rho)$ of the injection-moulded disks was measured with Archimedes' method and also determined from the weight and dimensions. The values were equal within $0 \cdot 1 \mathrm{~g} / \mathrm{cm}^{3}$.

Young's modulus $(E)$ and Poisson's ratio $(v)$ were measured with the pulse-echo method. Longitudinal waves at $5 \mathrm{MHz}$ and transverse waves at $20 \mathrm{MHz}$ were used and no correction for damping was made.

The strength $(\sigma)$ was determined with the ball-onring (BOR), the ring-on-ring (ROR) and with the

Table 2. Pore volume of cylinders debinded up to different temperatures

\begin{tabular}{lccccc}
\hline & \multicolumn{5}{c}{ Maximum temperature $(\mathrm{C})$} \\
\cline { 2 - 6 } & 200 & 250 & 300 & 350 & 400 \\
\hline $\mathrm{V}(\mathrm{MIP})\left(\mathrm{cm}^{3} / \mathrm{g}\right)$ & 0.050 & 0.080 & 0.109 & 0.133 & 0.133 \\
$\mathrm{~V}(\mathrm{Calc})\left(\mathrm{cm}^{3} / \mathrm{g}\right)$ & 0.047 & 0.080 & 0.111 & 0.138 & 0.138 \\
\hline
\end{tabular}

$\mathrm{V}(\mathrm{MIP})$ and $\mathrm{V}$ (Calc.) indicate the pore volume as measured with MIP and calculated from weight and size data, respectively. 
three-point bend test (3PB). These tests were done similarly as described before. ${ }^{5,6}$ For the BOR as well as for the ROR test injection-moulded disks were used with a diameter of $30 \mathrm{~mm}$ and a thickness of $1.5 \mathrm{~mm}$. For the ROR test the inner loading support had a diameter of $19 \mathrm{~mm}$. The disks tested were as-fired without any surface treatment. The surface roughness of the disks was $R_{\mathrm{a}}=0.4 \mu \mathrm{m}$, while the flatness was $0.2 \mathrm{~mm}$. The precise dimensions were measured with a screw micrometer (Mitutoyo 293$501)$. During the test a dew point lower than $-40^{\circ} \mathrm{C}$ was kept. The crosshead speed of the universal testing machine (Zwick 1445 ) was $0.1 \mathrm{~mm} / \mathrm{min}$. The $3 \mathrm{~PB}$ specimens were diced from the injectionmoulded disks to $15 \times 3 \times 1 \mathrm{~mm}^{3}$. The tensile side was ground. The span was $12 \mathrm{~mm}$. The crosshead speed of the tensile tester (Overload dynamics 8200 ) was $0.1 \mathrm{~mm} / \mathrm{min}$ and the dew point was kept below $-40 \mathrm{C}$. The Weibull modulus $(m)$ and characteristic strength $\left(\sigma_{0}, 63 \%\right.$ failure probability) were calculated using the failure probability estimator $P=(i-0.5) / N$ and a linear least-squares fit procedure with no weight function. Here $i$ represents the order number of the specimen, ranked in order of increasing strength, and $N$ the total number of specimens. All correlation coefficients were at least 0.98 .

The fracture toughness $\left(K_{\mathrm{Ic}}\right)$ was determined using the $3 \mathrm{~PB}$ specimen size with the single edge-notched beam test (SENB). This specimen size makes efficient use of the available material while retaining accuracy and reliability. ${ }^{7}$ The specimens contain a notch of $0.1 \mathrm{~mm}$ width and $0.4 \mathrm{~mm}$ depth positioned halfway on the $1 \times 15 \mathrm{~mm}^{2}$ surface. A Knoop indentation with $20 \mathrm{~N}$ load was positioned at the end of the notch on both surfaces to obtain a straight crack front. The depth of the notch was measured optically.

The Vickers hardness $\left(H_{v}\right)$ was measured on a polished test disk with a micro-indenter (Leitz miniload 2) with a load of $19 \cdot 61 \mathrm{~N}$ for $30 \mathrm{~s}$.

\subsection{Results and comparison with other Y-TZP materials}

To compare the present Y-TZP material with commercially available Y-TZP ceramics, the previously mentioned tests were performed on commer- cial materials as well as on the present materials. The commercially available materials both contained $3 \mathrm{~mol} \% \mathrm{Y}_{2} \mathrm{O}_{3}$ but were, as far as can be judged from the appearance of the as-delivered blocks, consolidated by pressing. The results are given in Table 3 .

It can be concluded that the material manufactured by injection moulding has mechanical properties comparable to those of the commercially available Y-TZP. The density is somewhat less and this affects the Young's modulus. The fracture toughness is for the same reason somewhat lower when compared with the commercial materials. The hardness of the three materials is equal. The bending strength of the present Y-TZP is higher than the strength of the other two materials, although for one material the difference is not significant at the $95 \%$ confidence level. The Weibull modulus obtained is intermediate between those for the commercial materials. In view of the slightly lower toughness yet somewhat higher strength, it may be concluded that on average a somewhat smaller defect size has been reached as in the commercially available materials.

\subsection{Influence of the mixing time on the strength}

The homogeneity of an injection-moulded product is largely influenced by the mixing process. To obtain some insight into the efficiency of the process and the change of homogeneity with mixing time, two batches of the recipe mentioned earlier were made. The first was mixed for $1 \mathrm{~h}$ after all the ceramic powder was added and the second for $2 \mathrm{~h}$. Injection-moulded disks made from the batches were tested in ROR and BOR measurements. In Table 4 the strength data are given.

The bending strength of the disks made from the different batches is the same. The Weibull modulus of the disks from the second batch is somewhat lower in both the BOR and ROR measurements. A mixing time of $2 \mathrm{~h}$ apparently gives no better homogeneity. The extra time only gives more wear of the mixer housing and blades which could lead to pollution of the mass and consequently to a lowering of the Weibull modulus. However, an increase in iron and aluminium impurities could not be detected by induction-coupled plasma (ICP) emission spectroscopy. Both the as-received powder and the

Table 3. Mechanical properties of the present Y-TZP and two commercially available Y-TZP ceramics

\begin{tabular}{|c|c|c|c|c|c|c|c|c|}
\hline Material & $\begin{array}{c}\rho \\
\left(\mathrm{g} / \mathrm{cm}^{3}\right)\end{array}$ & $\begin{array}{c}E \\
(G P a)\end{array}$ & r & $\begin{array}{c}K_{\mathrm{lc}} \\
\left(M P a_{\sqrt{ }} m\right)\end{array}$ & $\underset{(G P(l)}{\mathrm{H}_{\mathrm{v}}}$ & $N$ & $\left(\stackrel{\sigma_{\circ}}{M} \stackrel{(a)}{P}\right.$ & $m$ \\
\hline Present & $5 \cdot 80$ & 191 & $0 \cdot 303$ & $7 \cdot 7$ & $10 \cdot 8$ & 34 & 1254 & $10 \cdot 8$ \\
\hline $\mathrm{D}$ & $5 \cdot 86$ & 208 & $0 \cdot 321$ & $7 \cdot 9$ & $11 \cdot 4$ & 28 & 1002 & 15.5 \\
\hline $\mathrm{F}$ & $6 \cdot 03$ & 210 & 0.291 & $9 \cdot 6$ & $11 \cdot 4$ & 23 & 1198 & 8.7 \\
\hline
\end{tabular}

Strength parameters $N, \sigma_{0}$ and $m$ refer to the 3PB test. $N$ denotes the number of specimens used. For other symbols, see Section 4.1. D and F denote Y-TZP ceramic from Dynamic Ceramic and Feldmühle, respectively. 
Table 4. BOR and ROR strength data of sintered disks

\begin{tabular}{lccccccc}
\hline & \multicolumn{3}{c}{$B O R$} & & & \multicolumn{3}{c}{$R O R$} \\
\cline { 2 - 4 } \cline { 6 - 8 } & $\sigma_{\mathrm{o}}(M P a)$ & $m$ & $N$ & & $\sigma_{\mathrm{o}}(M P a)$ & $m$ & $N$ \\
\hline 1 h mixing & 934 & $7 \cdot 8$ & 25 & & 477 & 6.5 & 25 \\
2 h mixing & 922 & $5 \cdot 4$ & 30 & & 513 & $5 \cdot 4$ & 30 \\
\hline
\end{tabular}

$N$ is the number of specimens used for BOR and ROR strength test. For other symbols, see Section 4.1

powder after mass preparation contained $0.005 \mathrm{wt} \%$ $\mathrm{Al}_{2} \mathrm{O}_{3}$ and $0.004 \mathrm{wt} \% \mathrm{Fe}_{2} \mathrm{O}_{3}$.

\section{Size and Shape Reproducibility}

The shape and dimensions of injection-moulded products are determined by:

-The shape of the mould cavity: the size of the cavity, the surface roughness, wear traces, mould parting lines, sprue shape and accuracy of mould inserts and ejector pins are important.

- Reproducibility of the injection moulding machine: injection pressure and speed, mass and mould temperature and screw plasticizer performance.

- Shrinkage by cooling in the mould cavity.

-Deformation after ejection as a result of the external ejection force or internal stresses built up during cavity filling and/or cooling.

-Deformation during binder removal which is dependent on the product shape and the support by the substrate. At elevated temperature the binder becomes weak. It reduces the friction between powder particles so that gravitation can cause deformation.

- Sintering shrinkage which is dependent on the temperature schedule and the homogeneity of the product.

\subsection{The size and shape measurements}

To obtain some insight into the reproducibility of the final product the size and shape of 13 injection- moulded shaver knives were measured. The injection-moulded mass came from one mixing batch. The products were sequentially injectionmoulded, their binder was removed and they were sintered together.

The size measurements were made with a screw micrometer (Mitutoyo 293-501). Radial and axial cam measurements were made on a roundness meter (Taylor-Hobson talyround 200). Cam measurements represent the difference in radius between the circumscribed and inscribed circle when a measured quantity is represented in a polar plot. Here the radial and axial cam denote the cam data for the radius and thickness, respectively. The radial cam and axial cam of the mould are measured on a roundness meter (Federal with Tesatronic TTA-20).

\subsection{Discussion about the reproducibility}

In Table 5 the results of the size measurements are given. The results show that the reproducibility is quite acceptable. The relative reproducibility, as judged from the statistical range of the measurements, is better for the diameter $(\sim 1.2 \%)$ than for the thickness $(\sim 3.7 \%)$, but the absolute reproducibility is better for the thickness. The radial cam and axial cam of the shaver blades are $\sim 25 \mu \mathrm{m}$ higher than in the mould cavity. From the roundness measurements no relation between radial and axial cam could be found. The axial cam can be influenced by the flatness of the substrate during binder removal. Whether the deformation is due to internal or external forces or due to nonuniform shrinkage during sintering is not investigated.

In Table 5 the diameter and thickness measure-

Table 5. Size data for shaver knives and test disks

\begin{tabular}{lcccccc}
\hline & Average & Maximum & Minimum & Range & $\begin{array}{c}\text { Standard } \\
\text { deviation }\end{array}$ & Mould \\
\hline Diameter $(\mathrm{mm})$ & 14.014 & 14.098 & 13.93 & 0.167 & 0.055 & 17.40 \\
Radial cam $(\mathrm{mm})$ & 0.027 & 0.044 & 0.013 & 0.031 & 0.011 & 0.004 \\
Thickness $(\mathrm{mm})$ & 0.789 & 0.805 & 0.776 & 0.029 & 0.0093 & - \\
Axial cam $(\mathrm{mm})$ & 0.0324 & 0.0480 & 0.019 & 0.030 & 0.0089 & 0.007 \\
$R_{\mathrm{a}}(\mu \mathrm{m})$ & 0.33 & 0.42 & 0.25 & 0.17 & 0.051 & $\sim 0.1$ \\
$T$ (Batch 1) $(\mathrm{mm})$ & 1.490 & 1.506 & 1.474 & 0.032 & 0.0067 & - \\
$T$ (Batch 2) $(\mathrm{mm})$ & 1.494 & 1.533 & 1.482 & 0.051 & 0.0094 & - \\
$D$ (Batch 1) $(\mathrm{mm})$ & 29.93 & 30.10 & 29.70 & 0.40 & 0.092 & - \\
$D$ (Batch 2) $(\mathrm{mm})$ & 29.95 & 30.20 & 29.80 & 0.40 & 0.100 & - \\
\hline
\end{tabular}

Data are gathered for 13 shaver knives and 53 and 60 disks for batch 1 and 2, respectively. $T$ and $D$ denote the thickness and diameter of the disks, respectively. The standard deviation is the standard deviation in the mean. 
ments of the test disks used for the strength tests are also given. The relative reproducibilities are about $1.3 \%$ and $2 \cdot 1 \%$, respectively. The range of the thickness variations from both batches is of the same order of magnitude as the range of the thickness variations of the shaver knives. The average thickness for the two batches is nearly the same. This shows that the reproducibility between different batches is excellent. It should be noted that wear of the mould is not included in view of the limited number of products produced.

\section{Conclusions}

Production of Y-TZP parts by injection moulding is feasible. Different kinds of shapes are produced ranging from large testing disks (diameter $61 \mathrm{~mm}$, thickness $2.3 \mathrm{~mm}$ ) to complex-shaped shaver knives.

It is shown that the particle size distribution changes during the plasticizing process and that deformation during binder removal, despite extra precaution, could not be prevented. To prevent abrupt gradient changes in the weight reduction curve of the binder removal process, a low heating rate and sufficient air flushing in the furnace are necessary. MIP measurements showed a constant pore size during binder removal with pore volume growth proportional to the weight reduction. A 'shrinking core' model for the binder removal is therefore proposed. Binder removal starts from the outer surface of the injection-moulded part. The pores are completely opened and they grow towards the centre of the part until the core of binder is completely removed. Oxidative degradation at the polymer gas interface and evaporation of the low molecular weight vehicles are therefore responsible for the binder removal.

Sintering of the material at $1400^{\circ} \mathrm{C}$ for $1 \mathrm{~h}$ proved to be adequate to reach $96.7 \%$ relative density, while maintaining a grain size of about $0.3 \mu \mathrm{m}$. Various tests proved that the mechanical behaviour of the injection-moulded parts was comparable to or better than that of commercially available Y-TZP materials. In particular a high (3PB) strength combined with a reasonable Weibull modulus of about 11 is obtained. Increased plasticizing time did not significantly change the (biaxial) strength, indicating adequate homogeneity. The surface roughness of the as-fired products is largely determined by the grain structure and residual porosity. The shape reproducibility, as shown by the statistical range of various size measurements on injectionmoulded complex-shaped shaver knives and simple disks, was $1-3 \%$, but is highly dependent on shape and product support during binder removal.

\section{Acknowledgement}

Many thanks are due to Mr F. Vries for the clear and useful introduction to ceramic injection moulding. Without his experience much more time would have been required to achieve the present result.

\section{References}

1. German. R. M.. Powder Injection Molding. Metal Powder Industries Association, Princeton, 1990.

2. Edirisinghe, M. J. \& Evans, J. R. G., Review: fabrication of engincering ceramics by injection moulding. 1. Materials sclection. Int. J. High Tech. Ceram., 2 (1986) 1-31.

3. Wright. J. K., Evans, J. R. G. \& Edirisinge. M. J., Degradalion of polyolefin blends used for ceramic injection moulding. I. Am. Coram. Soc. 72 (1989) 1822--8.

4. Stangle. G. C.. Rhee, D. \& Aksay, I. A., Removal of processing aids from ceramic/polymer composites. Mat. Res. Soc. Simp. Proc., 155 (1989) 171-8.

5. Scholten. H., Dortmans, L. de With. G., de Smet, B. \& Bach, P.. Weakest-link failure prediction for ceramics. II. Design and analysis of uniaxial and biaxial bend tests. $J$. Eur. Crram. Soc. 10 (1992) 101 9.

6. de With, G., High temperature fracture of boron carbide: experiments and simple theoretical models. J. Mater. Sci., 19 (1984) 457-66.

7. de With. G. \& Hattu, N., On the use of small specimens in measurement of the fracture toughness for brittle materials. J. Mater. Sici. 16 (1981) 1702-4. 